\title{
CAPACITY DESIGN OF RC MULTI-STOREY FRAME ACCORDING TO EN 1998-1
}

\author{
Anka Starčev-Ćurčin* \\ Faculty of Technical Sciences, University of Novi Sad, Novi Sad, Serbia \\ Dr Đorđe Lađinović \\ Faculty of Technical Sciences, University of Novi Sad, Novi Sad, Serbia \\ Aleksandra Radujković \\ Faculty of Technical Sciences, University of Novi Sad, Novi Sad, Serbia \\ Andrija Rašeta \\ Faculty of Technical Sciences, University of Novi Sad, Novi Sad, Serbia
}

The method of capacity design requires the ductility of reinforced concrete load-bearing elements and provides the beam plasticity mechanism for a structure to absorb a significant seismic energy. Indeterminate static systems are particularly suitable, where an indefinite number of static indeterminacy determines the number of plastic hinges being forming, thus achieving favourable energy dissipation. In this paper, reinforced concrete five-storey frame is designed for two ductility classes according to the regulations EN1992-1-1 and EN1998-1.

Key words: Capacity design, Reinforced concrete frame, Ductility, Plastic hinges

\section{INTRODUCTION}

In the exploitation phase, due to the effect of gravity loads, bearing structure remains within the linear elastic behaviour of materials [1]. Due to the effect of the seismic load, bearing elements exceed the nonlinear work domain of materials [02].

The difference of the aforementioned loads, in the reinforced-concrete structures, may be reflected in the fact that, for example, in the bending element for the case of normal loads, compressed and tensioned zones over the intersection height remain unchanged, while during the seismic load multiple changes may occur in the said zones. Then, the shear forces in beams, due to the effect of the gravity load, cause slope cracks in one direction, while due to seismic loads, slope cracks occur in two perpendicular directions. Adhesion anchorage of the longitudinal reinforcement, during the normal loads, does not change the stress direction, but during the action of seismic loads the stress direction is constantly changed. Increased bending capacity in the structures due to seismic loads may increase shear forces and cause undesirable transverse fracture.

These differences lead to different approaches in designing and detailing of structural elements when the impact of seismic loads is introduced in the design.

\section{CAPACITY DESIGN REGULATIONS ACCORDING TO EN1998-1}

During the action of seismic load, the structure response depends on the behaviour of vertical load-bearing elements. In this paper, the emphasis will be placed on reinforced concrete frame structures.

For reinforced concrete structures according to EN1998-1, [02], the method of programmed behaviour of the load-bearing elements (method of capacity design) is used. It includes calculations and detailing in the design of a structure.The method requires selecting the places in the bearing structure in which the plastification will occur in order to achieve a favourable plastic mechanism. Selected places are dimensioned and detailed so as to reach the desired degree of ductility. Other parts of the structure are designed with extra load capacity (capacity) to remain in the elastic range of work materials. In the formation of plastic hinges in multi-storey buildings, the beam mechanism of the plastification in the structure is acceptable, and plastic hinges occur in the frame beams and columns in the base. 
The creation of the plastic hinges in the columns results in a relatively large rotation of the structure which makes that kind of mechanism unacceptable as compared to the beam mechanism. In order to avoid the plastic hinges in columns, in frame structures exposed to the effects of seismic loads, during the design, the principle that the column bending capacity is greater than the capacity of the beam bending (the "strong columns-weak beams") must be fulfilled. In the beam-column joint, it is difficult to provide ductile behaviour; therefore, outside the inner zone of the frame joints, the formation of plastic hinges must be achieved by detailing.

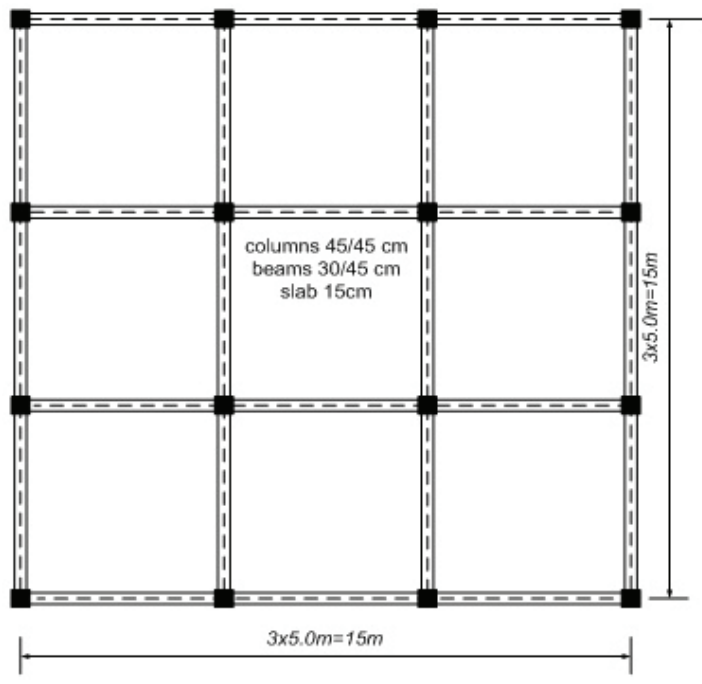

Figure 1: Floor plan and the cross-section of the structure

As the structure satisfies the criteria of the regularity basis, it can be analyzed as $3 \mathrm{D}$ or as $2 \mathrm{D}$ structure, [02]. Numerical analysis uses the planar model of the inner frame with the T-section beam and the effective width of $170 \mathrm{~cm}$. All columns are fixed in rigid foundation. In order to consider the influence of cracks, flexion and shear properties of the elements are reduced to the half of the uncracked section values. For the ductility class DCM concrete class C25/30 is used, and for the ductility class $\mathrm{DCH}$ concrete class $\mathrm{C} 35 / 45$ is used, with the Poisson ratio $v=0$ (cracked concrete), and steel S500 class C. In order to satisfy the condition of anchoring and continuing the longitudinal reinforcement beam bars in the node, [02], and not to increase the dimensions of the columns, the higher concrete class for the frame of the ductility class DCH has been adopted. The permanent load " $G$ " includes the self weight of the elements and the dead added permanent load in the amount of $2.5 \mathrm{kN} / \mathrm{m} 2$.

\section{NUMERICAL EXAMPLE}

Five-storey structure is designed according to EN1992-1-1 and EN1998-1 for two ductility classes, medium DCM and high DCH. For the analysis, software packages TOWER7 and SAP2000 V14-2 have been used.

The base of the analysed five-storey structure and the cross-section of the building are shown in Figure 1. The structure is symmetrical in both directions, with the range of $3 \times 5 \mathrm{~m}$ and the storey height of $3 \mathrm{~m}$. Slab thickness is $15 \mathrm{~cm}$, cross-sectional dimensions of beams are $30 / 45 \mathrm{~cm}$, while the dimensions of the columns are $45 / 45 \mathrm{~cm}$.

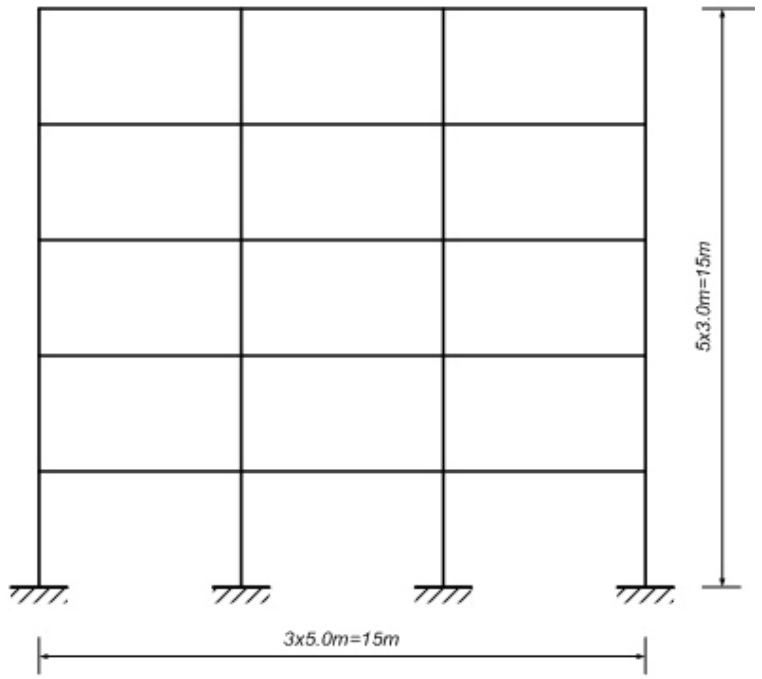

The imposed load " $Q$ " for the building category $\mathrm{B}$, according to [03], is taken as equally distributed with $2.5 \mathrm{kN} / \mathrm{m} 2$ intensity. Moment diagrams of permanent and imposed loads are shown in Figure 2.

The seismic action is represented by the horizontal elastic response spectrum of type 1 and the soil category $\mathrm{C}$ with a maximum acceleration of soil $0.2 \mathrm{~g}$. Values of the period and soil factor that describe the shape of the elastic response spectrum are TB $=0.2 \mathrm{~s}, \mathrm{TC}=0.6 \mathrm{~s}, \mathrm{TD}=2 \mathrm{~s}, \mathrm{~S}=1.15$, and for the damping correction factor is $\eta=1$. The building is classified as a building of significant class II and the importance factor is $y=1$.

Elastic analysis is carried out based on the design response spectrum, which is reduced in comparison to the elastic spectrum using the behaviour factor $q$. The value of the design seismic load determined for the ductility class DCM is $q=3.9$ and for the ductility class $\mathrm{DCH}$ is $\mathrm{q}=5.85$. 


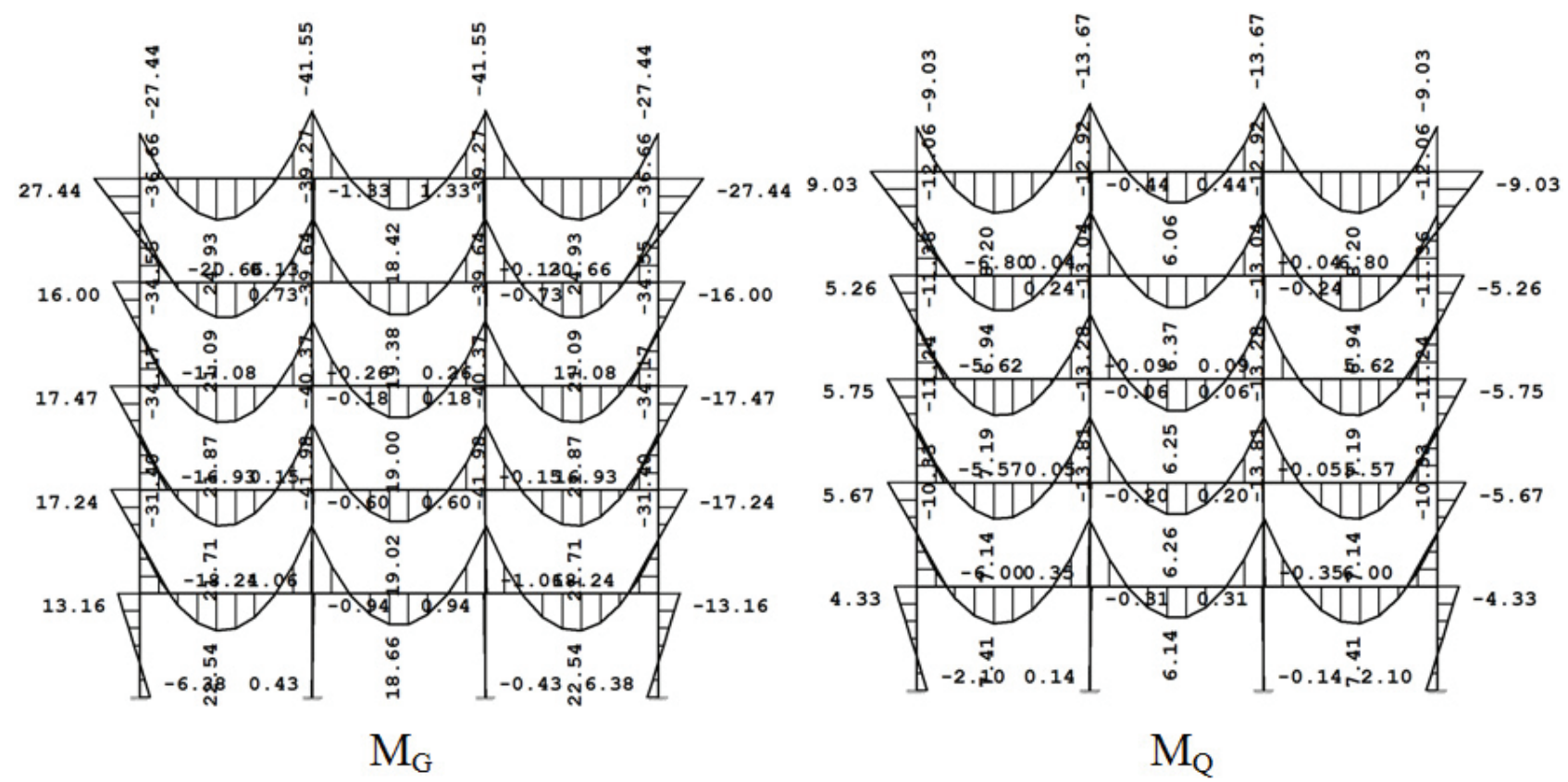

Figure 2: Moment diagrams of permanent and imposed loads

For the design of the forces of the seismic impact, the multimodal spectral analysis is applied and the impacts of the first two vibration modes are being considered, [02]. Inertial effects of the seismic design action are calculated based on the weight associated with all gravity loads (permanent and imposed) that occur in the corresponding combined actions of roof $\mathrm{G}+0.3 \mathrm{Q}$, and for other stories $G+0.15 Q$, [4]. The mass of the top storey of the frame structure is $53.57 \mathrm{t}$, and for other stories is $54.2 \mathrm{t}$. The total mass of the designed frame structure is $271.65 \mathrm{t}$. The shape and values of moments due to seismic forces $E$ and $-E$ for vibration periods of two dominant tones, for the first $\mathrm{T} 1=0.8288 \mathrm{~s}$ and the second $\mathrm{T} 2=0.2663 \mathrm{~s}$ for ductility class DCM, and for vibration periods of two dominant tones, for the first $\mathrm{T} 1=0.791 \mathrm{~s}$ and the second $\mathrm{T} 2=0.254 \mathrm{~s}$ for ductility class $\mathrm{DCH}$, are shown in Figure 3.

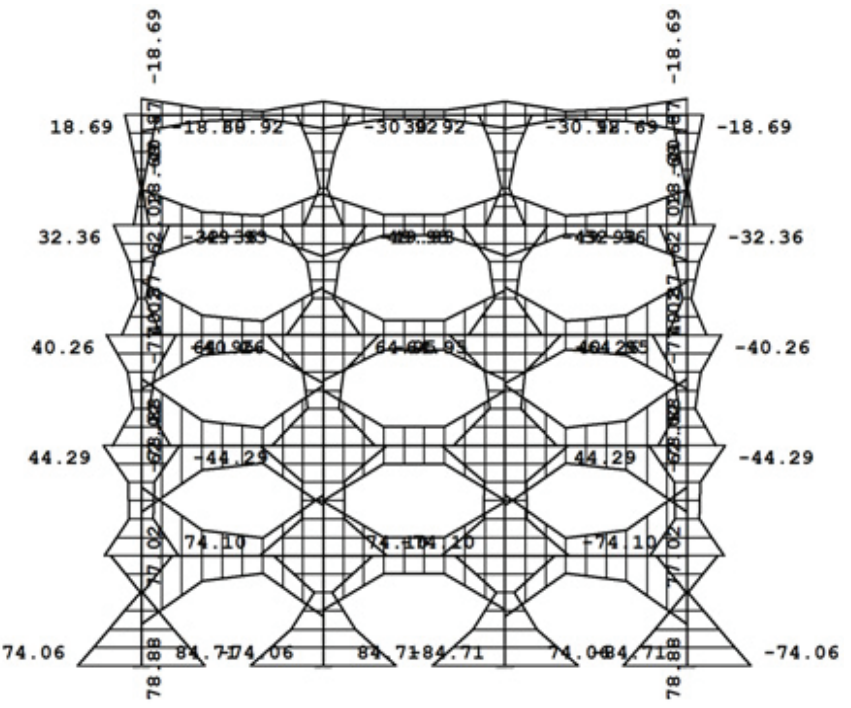

$\mathrm{M}_{\mathrm{E}, \mathrm{DCH}}$

$\mathrm{M}_{\mathrm{E}, \mathrm{DCM}}$

Figure 3: Moments due to seismic forces $E$ and $-E$, for $D C M$ and $D C H$

According to EN 1992-1-1, [01] based on the force envelope of the load combination, the observed frames are dimensioned. Regulative EN 1998-1, [02], for both classes of ductility, DCM and $\mathrm{DCH}$, requires the design regulative for the ultimate limit state, as well as detailing and fulfilling the required bending and shear capacity, and local ductility in beams and columns of dimensioned elements of the frame. 
Fulfilment of the local ductility, which implies the fulfilment of the maximum value of the tensioned and compressed reinforcement coefficients, in both ductility classes, demands for the increase of the compressed reinforcement in the supporting sections. Regulative on the local ductility, [2], reduces the distance between the transverse reinforcement, stirrups, in the ductility class $\mathrm{DCH}$. Based on these adjustments that are required to control capacity and design details, the new amounts of longitudinal and transverse reinforcement are adopted, as shown in Figure 4 for the ductility class DCM and in Figure 5 for the ductility class $\mathrm{DCH}$.
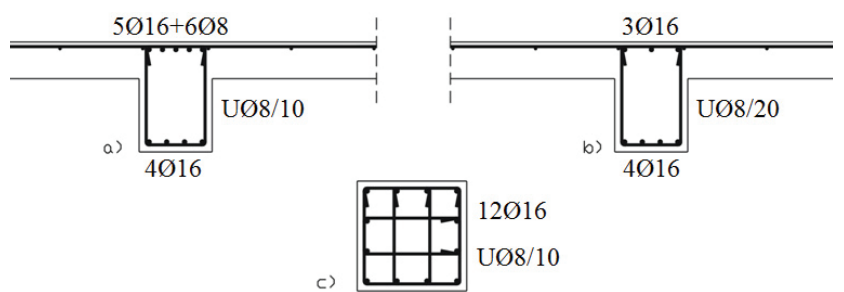

Figure 4: Addopted reinforcement for DCM according to EN1998-1: a) beam-support, b) beam-field and c) column

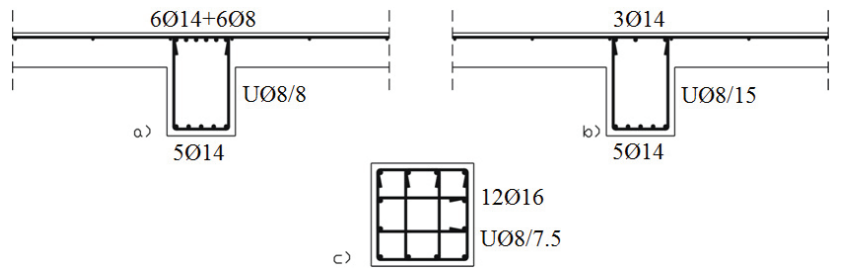

Figure 5: Addopted reinforcement for $\mathrm{DCH}$ according to EN1998-1: a) beam-support, b) beam-field and c) column
The amount of reinforcement required by EN19921-1 does not fulfil the rules for the capacity control of the local and global ductility according to EN1998-1. In the frame of the ductility class DCM, the amount of the support compressed reinforcement is increased from $3 \varnothing 16$ [6.03cm2] to $4 \varnothing 16$ [8.04cm2], and in the frame of the ductility class $\mathrm{DCH}$ from $3 \varnothing 14$ [4.62cm2] to $5 \varnothing 14$ [7.7cm2]. The change in the amount of transverse reinforcement occurs in the frame of the ductility class $\mathrm{DCH}$. The amount of stirrups is increased from $\varnothing 8 / 10[5 \mathrm{~cm} 2 /$ $\mathrm{m}$ '] to $\varnothing 8 / 8$ [6.25cm2/m'] in the beam-support, and in the beam-field from $\varnothing 8 / 20\left[2.5 \mathrm{~cm} 2 / \mathrm{m}^{\prime}\right]$ to $\varnothing 8 / 15$ [3.33 $\left.\mathrm{cm} 2 / \mathrm{m}^{\prime}\right]$. In the column the amount is increased from $\varnothing 8 / 10\left[5 \mathrm{~cm} 2 / \mathrm{m}^{\prime}\right]$ to $\varnothing 8 / 7.5\left[6.67 \mathrm{~cm} 2 / \mathrm{m}^{\prime}\right]$.

\section{Nonlinear static "pushover" analysis}

For nonlinear analysis, the cross-sections are presented as: confined part of the section (the core), unconfined part of the section (a protective layer of concrete to reinforcement) and reinforcement. Relation stress-strain for unconfined and confined part of the cross-section for beam-support and column, for the concrete classes C25/30 and C35/45 and for the steel S500 are shown in Figure 6.

Target displacement of ductility class DCM frame for the modal pattern of the forces is $D=10.75 \mathrm{~cm}$, and for the uniform pattern is $D_{t}=9.21 \mathrm{~cm}$. In the frame of the ductility class $\mathrm{DCH}$, for the modal pattern of forces, target displacement is $D_{t}=10.52 \mathrm{~cm}$, and for the uniform pattern is $D_{\mathrm{t}}=8.93 \mathrm{~cm}$. In Figure 7, the curves of the capacity for specific target displacement are shown.
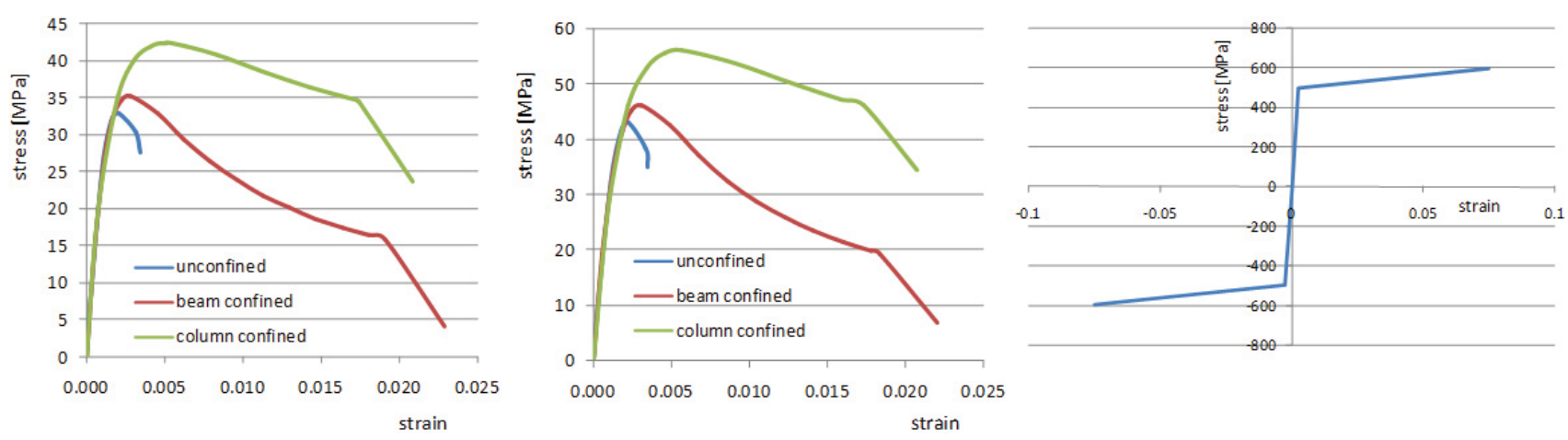

Figure 6: Relation stress-strain for conncrete C25/30 and C35/45 and for steel S500

It is observed the higher shear forces are in the grounds of the building for the uniform pattern. The interstorey drift of the frames for ductility classes DCM and DCH due to the effect of the modal and uniform pattern are shown in Figure 8. Structural behaviour estimate based on "pushover" analysis in the frame of the ductility class
DCM, for the modal pattern of forces, is determined by the value of the overstrength ratio au/a1 which is 1.35 , and for the uniform pattern of forces, $\alpha_{u} / \alpha_{1}$ value is 1.38 . For the frame of the ductility class $\mathrm{DCH} \alpha_{u} / \alpha_{1}$ value is 1.42 for the modal pattern of forces and for the uniform pattern of forces arranged by height frame, $\alpha_{u} / \alpha_{1}$ value is 1.52 . 
Results oh the "pushover" analysis show that, for the adopted characteristics of the frame, there is an additional capacity, because the adopted value $\alpha_{u} / \alpha_{1}=1.3$, at the beginning of the design, is lower than the value obtained from the $\alpha_{u} / \alpha_{1}$ of the "pushover" analysis.
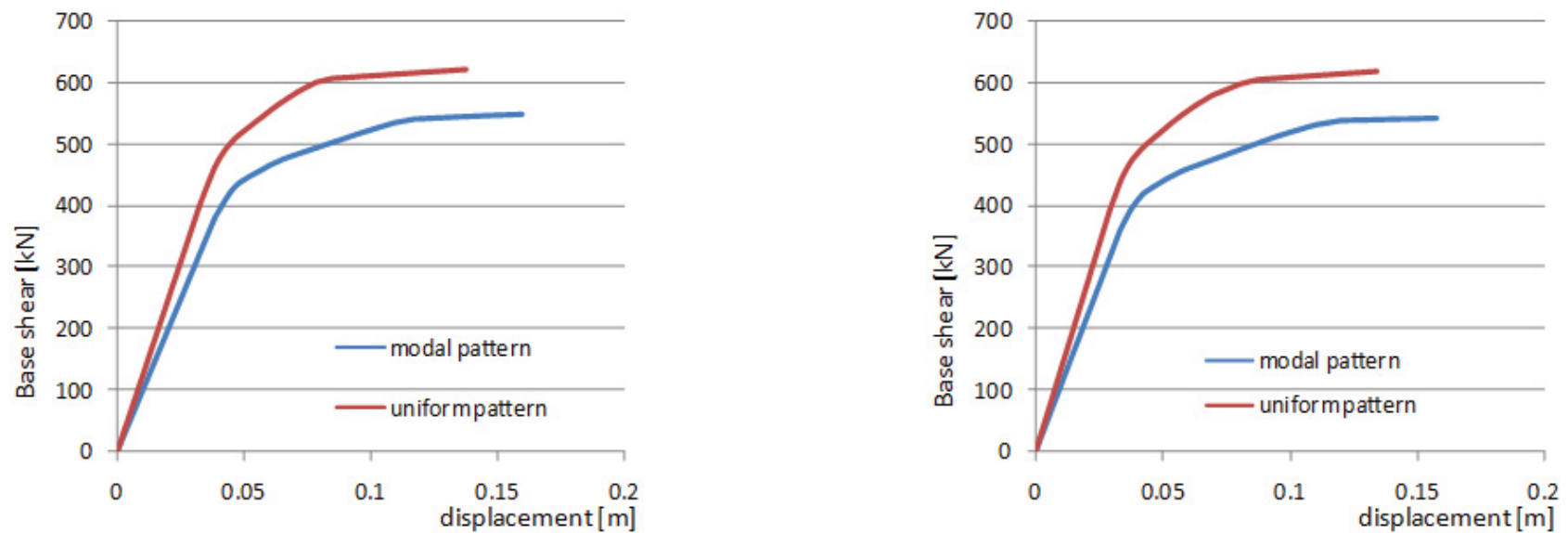

Figure 7: Capacity curve of the frame for the ductility classes DCM and DCH
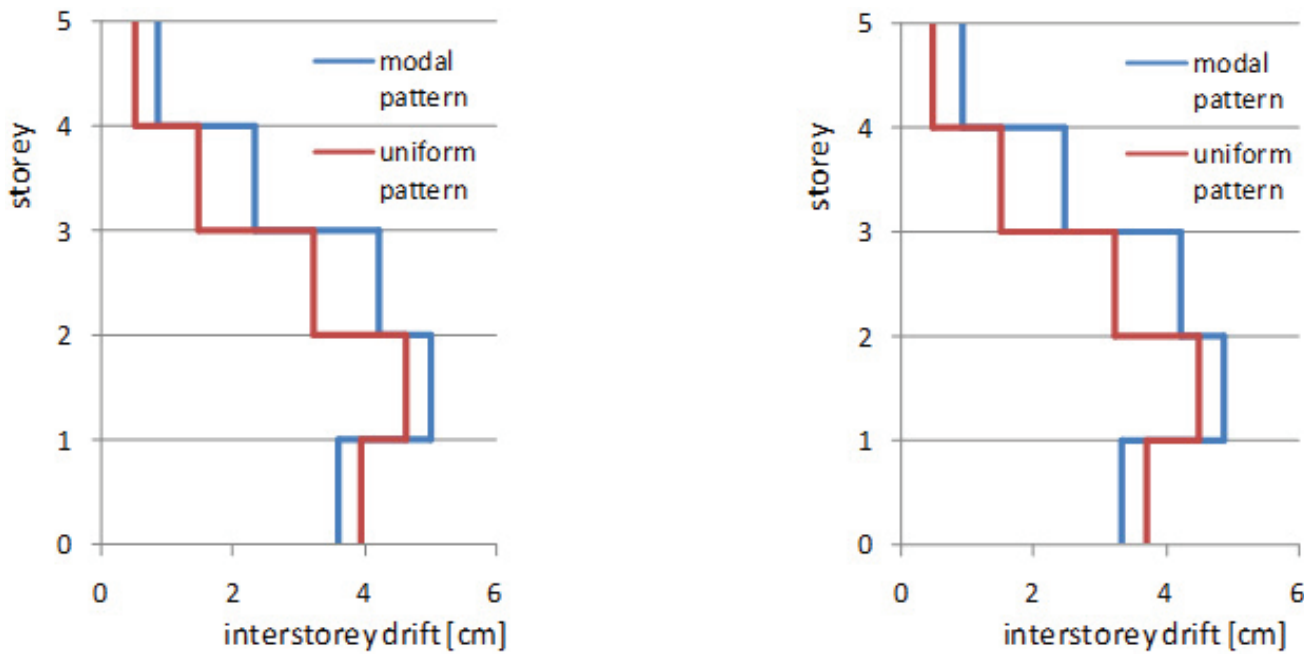

Figure 8: Interstorey drift of the frames for the classes $D C M$ and $D C H$
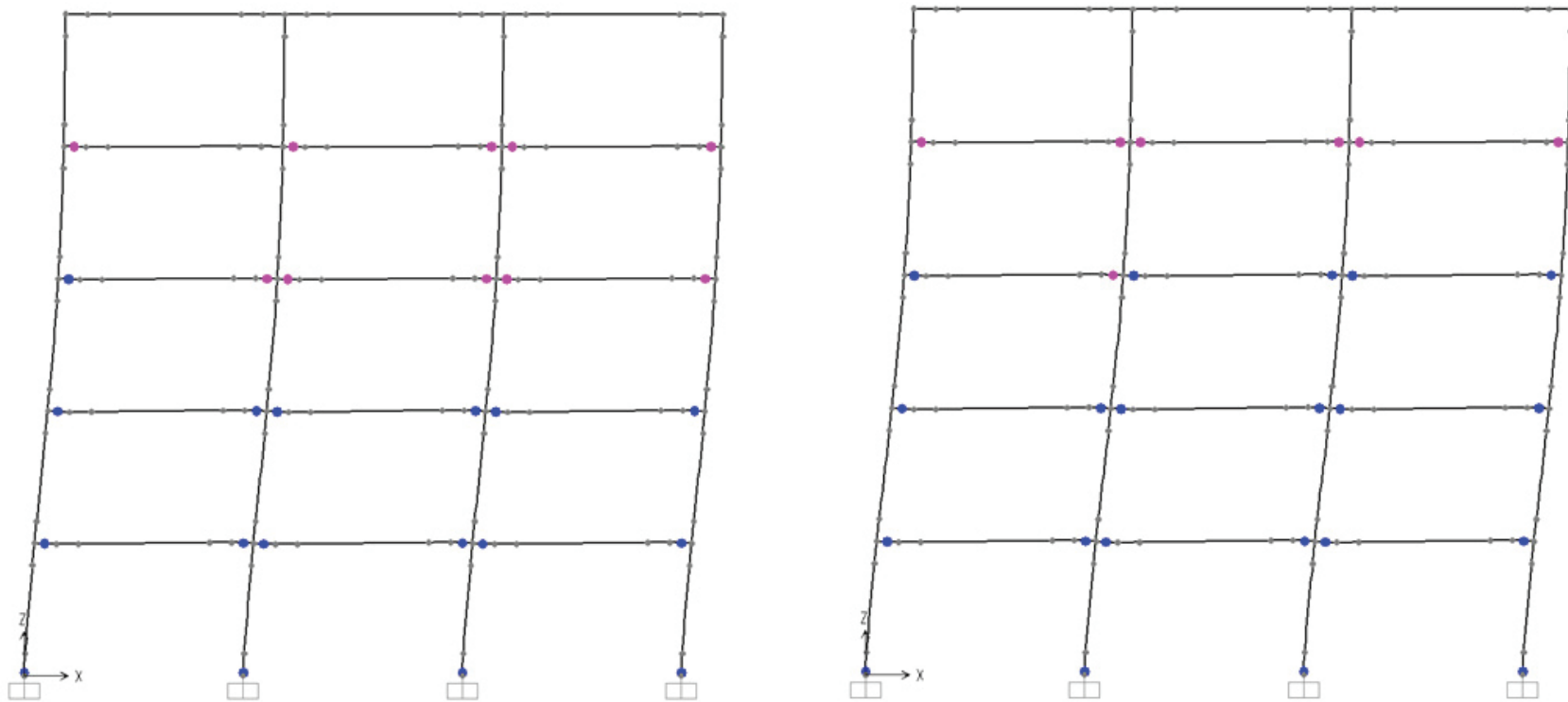

Figure 9: Formation of the plastic hinges for a) DCM and b) DCH for target displacement 
The development of the plastic hinges mechanism in both structures is favorable. Plastic hinges are formed at the ends of beams and columns in the base. In both structures plastic hinges occur at the same places and in the same number. There was a difference only in the larger plastification of the hinges of the fourth-floor beams in the structure of the ductility class $\mathrm{DCH}$.

\section{CONCLUSION}

The correct behaviour of reinforced concrete structures, i.e. the acceptance of the seismic energy without significant damage to the loadbearing elements at higher intensities of earthquakes, involves the selection of the structure, which is reflected in its simplicity, and its symmetry both at the base and in the height, as well as its load capacity, stiffness and ductility.

The analysis of the five-storey reinforced concrete frame shows that sections designed according to EN1992-1-1, [01], do not fulfil the regulative required by EN1998-1, [02], for both classes of ductility, and therefore they have to be revised and new required reinforcement amounts have to be adopted, Figures 4 and 5 . In the frame of the ductility class DCM, the amount of longitudinal reinforcement is increased for $33 \%$, and in the frame of the class $\mathrm{DCH}$ for $66 \%$. The change in the amount of transverse reinforcement occurs in the ductility class DCH which is increased in beams for $25 \%$, and in columns for $33 \%$.

Conditions required by the ductility class $\mathrm{DCH}$ are stricter than the conditions required by the ductility class DCM. Seismic forces at DCH are smaller but the control of the capacity and ductility of the section is stricter. Comparing the reinforced sections of both ductility classes, it is noted that, as expected, the larger amount of reinforcement is in the class DCM, while it is lower in the ductility class $\mathrm{DCH}$. However, the demanded increase of the material quality led to the greater capacity in the ductility class $\mathrm{DCH}$ at the expense of the reduced ductility.

Based on the results of the "pushover" analysis, it is shown that the capacity curves for both ductility classes had no significant differences as a result of the relationship of strength and ductility of the frame elements on the basis of the adopted amount of reinforcement and material characteristics. For adopted characteristics of the frame, there is an additional structural capacity that can be seen from the values of multiplication factors obtained from the "pushover" analysis. The arrangement of the plastic hinge formation, Figure 9 , shows a favourable development of the plastic hinge mechanism since they are formed at the ends of beams and columns in the base in both structures of two ductility classes.

The results show that, for the analysed reinforced concrete frame, in the case of an earthquake of moderate intensity, there is no significant difference in choosing between ductility classes DCM and $\mathrm{DCH},[05]$. The considered structures and seismic effects show satisfactory capacity values, stiffness and ductility, and the results indicate that the reinforced concrete frame, in which the bearing elements are designed according to EN1998-1, [02], can accept the given seismic forces.

\section{ACKNOWLEDGEMENTS}

The work has been done within the scientific research project TR 36043 "Development and application of a comprehensive approach to the design of new and safety assessment of existing structures for seismic risk reduction in Serbia", which is funded by the Ministry of Science of Serbia.

\section{REFERENCES}

1) EN1992-1-1:2004, Proračun betonskih konstrukcija, deo 1-1: Opšta pravila $i$ pravila za zgrade. Beograd: Građevinski fakultet Univerziteta u Beogradu, 2006.

2) EN1998-1:2004, Proračun seizmički otpornih konstrukcija, deo 1: Opšta pravila, seizmička dejstva i pravila za zgrade. Beograd: Građevinski fakultet Univerziteta u Beogradu, 2009.

3) EN1991-1-1 Evrokod 1: Dejstva na konstrukcije. Deo 1-1: Zapreminske težine, Sopstvena težina, Korisna opterećenja za zgrade. Beograd, novembar 2009.

4) EN1990:2002, Osnove proračuna konstrukcija, Beograd: Građevinski fakultet Univerziteta u Beogradu.

5) Fardis M. Seismic Design, Assessment and Retrofitting of Concrete Buildings, Based on EN-Eurocode8, Spinger Dordrecht Heidelberg London New York, 2009.

Paper sent to revision: 07.02.2014.

Paper ready for publication: 15.03.2014. 